\title{
THE EFFECT OF RETAILER'S PRICE IMAGE ON PRICE FAIRNESS, CONSUMER SATISFACTION AND LOYALTY
}

\author{
MYUNG SU CHAE ${ }^{1} \&$ JINSEO PARK ${ }^{2}$ \\ ${ }^{1}$ Professor, Hankuk University of Foreign Studies, Seoul, South Korea \\ ${ }^{2}$ Research Scholar, Hankuk University of Foreign Studies, Seoul, South Korea
}

\begin{abstract}
Existing studies, which explain that price-related factors are one of several sub-dimensions of store image, are limited to describing how price image strategies of retailers have an impact on the consumer behavior. To describe that kind of impact, in this study, using the framework of perception - emotion - behavior perspective based on expectancy value theory, we explain the effect of retailer's price image on price fairness, consumer satisfaction and loyalty, focusing on the relationship between the retailer's price image and price fairness consumer perceived. The results identified that consumers perceive a retailer with low price image more fair than the other retailers, and indicated that the more fair consumers perceive, the more they are satisfied and the higher the repurchase intention and word of mouth. Moreover, the result also showed that price image fit, consumer perception of between actual product list price and retailer's price image, strongly moderate the relationship between the price image and the price fairness.
\end{abstract}

KEYWORDS: Retailer's Price Image, Price Fairness, Fit of Price Image, Moderating Effect

Received: May 25, 2017; Accepted: Jun 22, 2017; Published: Jul 12, 2017; Paper Id.: IJRMRAUG20171

\section{INTRODUCTION}

Although it is possible to easily access and compare prices of individual products through development in mobile internet, due to limitation of the accessible information and overwhelmed comparisons, consumers tends to make a purchase decision depending on the overall impression of the retailer's price rather than on prices of individual products (Hamilton and Chernev 2013). Since existing studies explain that price-related factors are one of several subdimensions of store image, there is limitation of describing how price image strategies of retailers have an impact on the consumer behavior. In addition, the conventional wisdom related to price research suggests that since consumers cannot recall most of the prices correctly (Vanhuele and Drèze 2002), they choose and visit any retailer store based on the knowledge of prices, the recall for price information including reference prices (Estelami and De Maeyer 2004). To overcome this kind of limitation for the information processing, some researchers have distinguished between objective product price and perceived price encoded and interpreted by the consumer. Since such a price have an impact on the formation of price related image (Zeithaml 1988; Zielke 2006), the formed price-related image may have an effect on both the consumer belief and behavior. However, these studies have focused on product price rather than on retailer's price image.

To explain how price image strategies of retailers have an impact on the consumer behavior, in this study, using the framework of perception - emotion - behavior perspective based on expectancy value theory, we explain the effect of retailer's price image on price fairness, consumer satisfaction and loyalty, focusing on the relationship between the retailer's price image and price fairness consumer perceived. 


\section{CONCEPTUAL UNDERPINNINGS AND HYPOTHESES DEVELOPMENT}

\section{The Impact of Retailer's Price Image on Price Fairness}

Because price images do not change well, when formed affect the fairness of consumers, the perceived fairness affects to keep holding consumers (Chebat and Slusarczyk, 2005), and price fairness can be an important consequence of price image. The price fairness reflects the degree to which consumers assess that, the retailer's prices are reasonable, acceptable, or justifiable relative to the prices its competitors charge(Campbell 1999), and the price image could be one of important factors for price fairness. From prior research (Bolton, Warlop, and Alba 2003), we can imply that in a store with a low price image consumers would be less likely to be perceived unfair than in a store with a high price image which led them to expect a higher price in advance. Moreover, some studies like Hamilton and Chernev (2013) and Zieike (2006) indicated that, because retailers with a higher price image are more likely to charge higher prices relative to the competition, consumers are likely to perceive their prices as unfair because they are not on par with those of the competition. Thus,

H1: Retailer's price image (PI) will have a negative impact on perceived price fairness of consumer (PF).

In the retailing, research related to fit is mainly focused on the fit of relationships between the self-congruity and retailer image, or core brands and brand extensions. For example, categorization process, which can transit from the assessment of core brand to the extended brands, will occur when the perceived similarity between the core brand and brand extension is higher (Boush and Loken 1991; Keller and Aaker 1992). Similarly, the categorization process, as means of evaluating the retailer's price image, will occur when the perceived fit between the price image presented by a retailer and the price image consumer perceived is higher. That is, the higher perceived fit is, the more associations linked with retailer's price image become to be related to associations linked with fairness. Therefore, we propose that retailer's price image affects consumers to perceive retailer's price fairness and the fit between a retailer's price image and actual list prices in the retailer moderate the influence of between retailer's price image and price fairness. Thus,

$\mathbf{H}_{\text {mod }}$ : The fit of price image have moderate effect on relationship between retailer's price image (PI) and price fairness $(\mathrm{PF})$.

\section{The Impact of Price Fairness on Consumer Satisfaction and Loyalty}

Xia, Monroe and Cox (2004) has argued that the perception of price fairness affect the evaluation of the consumer satisfaction and the product evaluation. Other researchers (Campbell 1999; Herrmann, Xia, Monroe, and Huber 2007; Oliver and Swan 1989) has identified that unfair price perception has effect on consumer satisfaction, purchase intention, or complaining behavior. Thus,

H2: Consumer perceptions of price fairness for a retailer $(\mathrm{PF})$ will have a positive impact on consumer satisfaction $(\mathrm{S})$.

Prior research has identified that trust is a necessary antecedent of loyalty. That is, fairness is an antecedent of trust (Buttle and Burton 2002) and trust is an antecedent of loyalty (Morgan and Hunt 1994), therefore, fairness can be an antecedent of loyalty. The reason why fairness is important is because; the breaking of trust could lead to the dissolution of the relationship between consumers and a firm (Sirdeshmukh, Singh and Sabol 2002). Therefore, consumers might recognize and believe that the retailer has broken the implicit trust of the relationship alone when they are aware that the 
retailer is engaging in unfair to them. Thus,

H3: Consumer perceptions of price fairness for a retailer (PF) will have a positive impact on retailer's loyalty.

H3-1: Consumer perceptions of price fairness for a retailer (PF) will have a positive impact on repurchase intentions $(\mathrm{R})$.

H3-2: Consumer perceptions of price fairness for a retailer (PF) will have a positive impact on word of mouth (W).

\section{The Impact of Consumer Satisfaction on and Loyalty}

So many researchers (Campbell 1999; Herrmann et al. 2007; Oliver and Swan 1989; Seiders, Voss, Grewal and Godfrey 2005) related to consumer behavior have identified that, when a consumer feel the satisfaction of the purchase, such a satisfaction on post-purchase have influence on loyalty such as repurchase intention, word-of-mouth behavior and complaints, and switching behavior. One of representative consequences for consumer satisfaction can be repurchase intention. Many empirical studies tested the relationship between consumer satisfaction and repurchase behavior have shown that repurchase behavior such as visiting for repurchase and repurchase spending has no significant relationship with consumer satisfaction, but repurchase intention has a positive impact on consumer satisfaction(Mittal and Kamakura 2001). In addition, word of mouth having great attention as an alternative measure of loyalty so far can be divided into positive and negative effect. That is, higher consumer satisfaction can lead to a positive word-of-mouth, or high consumer dissatisfaction a negative complaining behavior (Anderson, Fornell, and Mazvancheryl 2004; Kumar et al. 2013). Thus,

H4: Consumer satisfaction (S) will have a positive impact on retailer's loyalty

H4-1: Consumer satisfaction $(\mathrm{S})$ will have a positive impact on repurchase intentions $(\mathrm{R})$.

H4-2: Consumer satisfaction (S) will have a positive impact on word of mouth (W).

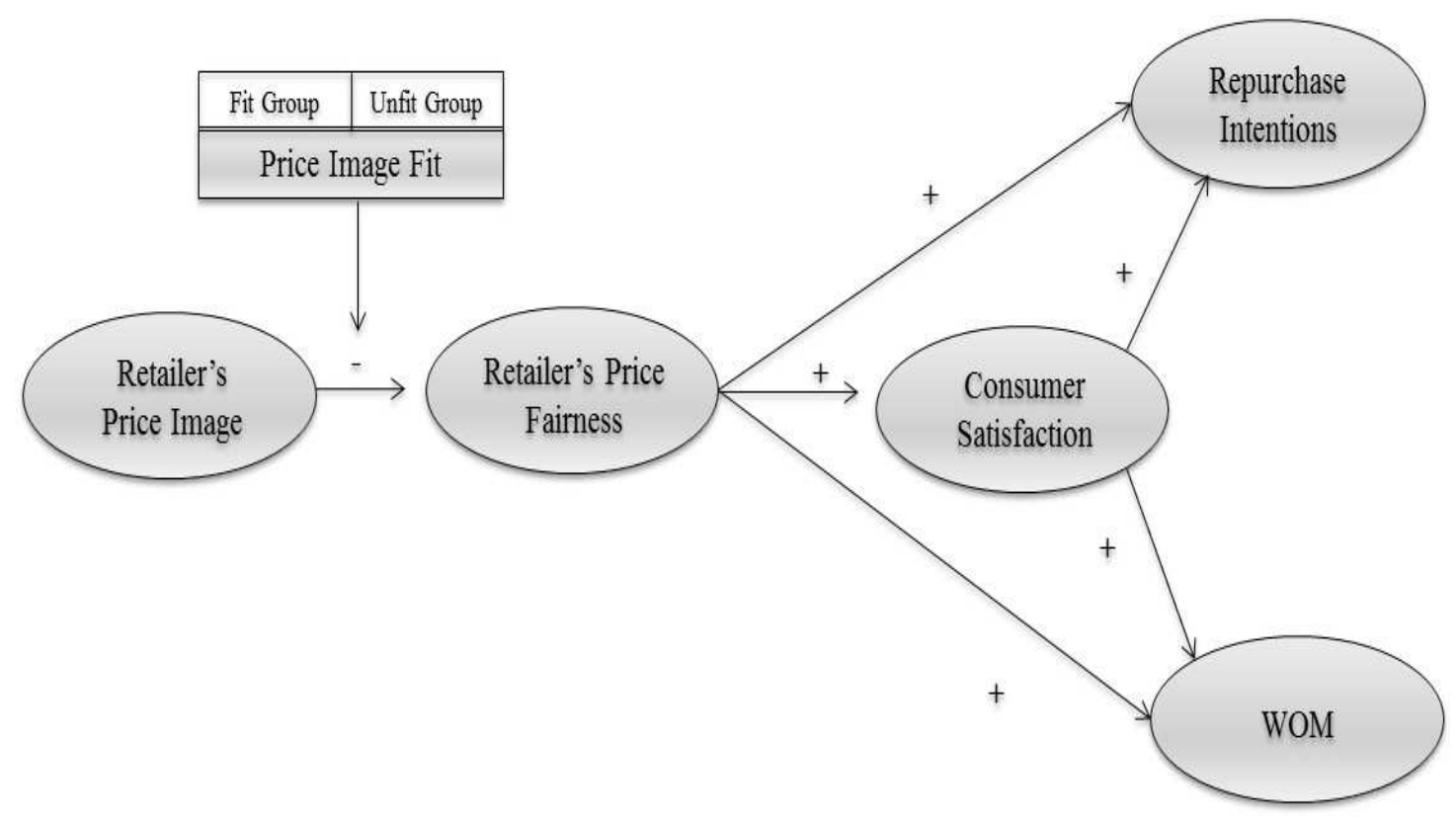

Figure 1: Research Model 


\section{EMPIRICAL ANALYSIS AND RESULTS}

\section{Data and Variables}

To test the hypotheses proposed above, we collected by person to person survey and web survey after pretest. Our research subjects were consumers in Korea who had at least one time vegetable purchase experience in groceries. The respondents were asked to fill out the questionnaire on paper or website. The main survey had 681 responses (Response rate $=34.1 \%$ ). A total of 14 were invalid, incomplete or gave the same rating for all items; these were eliminated, and thus 667 questionnaires were retained for analysis. Demographically, 51\% of the respondents were men; $41.1 \%$ were aged between 20 and 29; and 28.8\% were aged between 30 and 39; and 22.3\% were aged between 40 and 49 . Ninety-six percent of the respondents' education was at the institute/college level or above. $37.3 \%$ of the respondents were students, $37.3 \%$ of the respondents were housekeepers and $38.2 \%$ were employed. Approximately $72 \%$ of the respondents' monthly house income was over $\$ 4,000$. The recent place for buying vegetable were convenience store (22.3\%), department store (18.1\%), Korean traditional farmer's market (11.1\%), mart (42.0\%), online-store (3.0\%), and others (3.4\%). All items among the constructs were tested against demographic controls (age, gender, level of education and occupation) using Student's t-test or ANOVA. The mean scores of the items were all insignificant ( $\mathrm{p}>0.05)$, but, the mean scores of the items for price image fit-unfit group was significant $(\mathrm{p}<0.05)$; indicating the validity of analyzing the data as two groups.

Table 1: Summary of Measurement Scale

\begin{tabular}{|c|c|c|c|c|c|}
\hline Item & Measure & $\begin{array}{c}\text { Std. } \\
\text { Estimate }\end{array}$ & $T$-Value & $\mathbf{C R}$ & AVE \\
\hline PI1 & The prices are generally very low here & 0.80 & - & \multirow{4}{*}{0.89} & \multirow{4}{*}{0.89} \\
\hline PI2 & The price level is very high here & 0.85 & 24.85 & & \\
\hline PI3 & You can buy cheap groceries here & 0.87 & 25.32 & & \\
\hline PI4 & $\begin{array}{l}\text { The prices are cheaper here than in other } \\
\text { stores }\end{array}$ & 0.80 & 22.89 & & \\
\hline PF1 & The prices are understandable here & 0.83 & - & \multirow{4}{*}{0.88} & \multirow{4}{*}{0.88} \\
\hline PF2 & The prices are acceptable here & 0.86 & 26.71 & & \\
\hline PF3 & The prices are justifiable here & 0.84 & 25.76 & & \\
\hline PF4 & The prices are reasonable here & 0.82 & 24.65 & & \\
\hline S1 & $\begin{array}{l}\text { I am completely satisfied with shopping } \\
\text { here }\end{array}$ & 0.73 & - & \multirow{4}{*}{0.78} & \multirow{4}{*}{0.78} \\
\hline S2 & Shopping here is a delightful experience. & 0.80 & 19.04 & & \\
\hline S3 & $\begin{array}{l}\text { I am satisfied with my decision to visit this } \\
\text { retailer }\end{array}$ & 0.78 & 18.61 & & \\
\hline S4 & $\begin{array}{l}\text { My choice to visit this retailer was a wise } \\
\text { one. }\end{array}$ & 0.70 & 16.81 & & \\
\hline $\mathrm{R} 1$ & I have intentions to buy here again. & 0.79 & - & \multirow{3}{*}{0.80} & \multirow{3}{*}{0.80} \\
\hline $\mathrm{R} 2$ & Do business with this store in the future? & 0.73 & 18.74 & & \\
\hline R3 & $\begin{array}{l}\text { Would you repurchase here, if you had to } \\
\text { buy again? }\end{array}$ & 0.75 & 19.20 & & \\
\hline W1 & $\begin{array}{l}\text { I will say positive things about this store to } \\
\text { other people }\end{array}$ & 0.74 & - & \multirow{4}{*}{0.80} & \multirow{4}{*}{0.80} \\
\hline W2 & $\begin{array}{l}\text { I will recommend it to someone who seeks } \\
\text { my advice }\end{array}$ & 0.82 & 20.43 & & \\
\hline W3 & $\begin{array}{l}\text { I will encourage friends and relatives to } \\
\text { visit this store }\end{array}$ & 0.80 & 20.09 & & \\
\hline W4 & $\begin{array}{l}\text { How likely are you to recommend this store } \\
\text { to others? }\end{array}$ & 0.78 & 19.57 & & \\
\hline
\end{tabular}

Note: $t$-value is significant at $p<0.05$ when the $t$-value exceeds 1.96 . 


\section{Analysis of the Measurement Model}

We first developed the measurement model by conducting confirmatory factor analysis. The structural equation model was then estimated for hypotheses testing. The final measurement model with purified items yielded a chi-square value of 667 with 142 degrees of freedom $(p=0.00)$ and the ratio of chi-square to degrees of freedom $\left(\chi^{2} / \mathrm{df}=3.33\right)$. However, the other indices satisfied the recommended values $(\mathrm{GFI}=0.929, \mathrm{AGFI}=0.904, \mathrm{CFI}=0.958, \mathrm{NFI}=0.941$, and RMSEA = 0.05). With the final measurement model, each construct also was evaluated by examining the indicator loading, construct reliability, convergent validity, and discriminant validity. Table 1 is demonstrating adequate convergent validity. Lastly, discriminant validity was tested. AVEs of each paired construct are greater than paired construct correlation except the relationship between repurchase intentions and word of mouth.

\section{Hypotheses Testing Results}

Table 2 summarizes the empirical results of the structural equation model to test hypotheses. As you see, all hypotheses are supported.

Table 2: The Results of the Structural Equation Model

\begin{tabular}{|c|l|c|c|c|c|}
\hline & \multicolumn{1}{|c|}{ Hypothesized Relationship } & Parameter & Std. Estimate & $T$-Value & Conclusion \\
\hline H1 & Price image $\rightarrow$ Price fairness & $\gamma_{11}$ & -0.66 & -15.90 & Supported \\
\hline H2 & Price fairness $\rightarrow$ Consumer Satisfaction & $\beta_{21}$ & 0.58 & 12.50 & Supported \\
\hline H3-1 & Price fairness $\rightarrow$ Repurchase Intentions & $\beta_{22}$ & 0.27 & 5.86 & Supported \\
\hline H3-2 & Price fairness $\rightarrow$ WOM & $\beta_{23}$ & 0.31 & 6.62 & Supported \\
\hline H4-1 & $\begin{array}{l}\text { Consumer Satisfaction } \rightarrow \quad \text { Repurchase } \\
\text { Intentions }\end{array}$ & $\beta_{31}$ & 0.60 & 10.91 & Supported \\
\hline H4-2 & Consumer Satisfaction $\rightarrow$ WOM & $\beta_{32}$ & 0.47 & 8.88 & Supported \\
\hline \multicolumn{2}{|l|}{ Model fit index: $\chi_{(146)}^{2}=760.56, \chi^{2} / d f=5.21$, GFI=0.90, AGFI=0.86, CFI=0.92, NFI=0.91, RESEA=0.08 } \\
\hline
\end{tabular}

Note: $t$-value is significant at $p<0.05$ when the $t$-value exceeds 1.96 .

We used a multi-group analysis to test the moderating effect of price image fit. Respondents were split into fit and unfit groups based on their perceptions of price image fit (performing a median-split). A structural model linking price image with price fairness was constrained to force equal loading between the fit and unfit price image groups. A chi-square difference test was then conducted between the groups to identify whether their paths were significantly different. As shown in $\langle$ Table 3$\rangle$, the chi-square difference was $15.51(\mathrm{p}<0.001)$ for the price image - price fairness link, exceeding the critical value of 3.8 for one degree of freedom. H1 proposed a positive moderating effect of price image fit on the relationship between price image and price fairness.

Table 3: Chi-Square Difference Test between Fit and Unfit Price Image Group

\begin{tabular}{|c|c|c|c|c|}
\hline \multirow{2}{*}{ H1 } & \multicolumn{2}{|c|}{ Fit Group } & \multicolumn{2}{c|}{ Unfit Group } \\
\cline { 2 - 5 } & $\begin{array}{c}\text { Std. } \\
\text { Estimate }\end{array}$ & $T$-Value & Std. Estimate & $T$-Value \\
\hline Price image $\rightarrow$ Price fairness & -0.83 & -14.40 & -0.46 & -7.97 \\
\hline$\chi_{(292)}^{2}=923.82, \chi^{2} / \mathrm{df}=3.16$, GFI=0.87, AGFI=0.84, CFI=0.92, NFI=0.89, RESEA=0.05 \\
\hline \multicolumn{2}{|c|}{$\begin{array}{c}\text { Constrained } \\
\text { Model Fit Index }\end{array}$} & $\begin{array}{c}\text { Unconstrained } \\
\text { Model }\end{array}$ & $\Delta \chi^{2}$ \\
\hline$\chi^{2}$ (d.f.) & $939.33(293)$ & $923.82(292)$ & 15.51 \\
\hline GFI & 0.87 & 0.87 & \\
\hline
\end{tabular}




\begin{tabular}{|c|c|c|c|}
\hline \multicolumn{4}{|c|}{ Table 3: Contd., } \\
\hline AGFI & 0.83 & 0.84 & \\
\hline CFI & 0.92 & 0.92 & \\
\hline RMSEA & 0.05 & 0.05 & \\
\hline
\end{tabular}

Note: $t$-value is significant at $p<0.05$ when the $t$-value exceeds 1.96 .

\section{DISCUSSIONS}

\section{Practical Implications}

Practically, one of the strategic practices that a retailer's managers can take to develop and maintain the loyalty of their consumers is that among consumers the retailer will be perceived to be fair, and one of the ways to perceived to be fair is taking a low price image strategy. In addition, research on the moderating effect between price image and price fairness found that lower price image only doesn't lead to higher price fairness. That is, the another way to be perceived more fair for retailers is taking the pricing strategy that fit between lower price image and the actual prices of products in the image. The results of this study also showed that not only important to maintain a low price image does retailers maintain, but presenting the actual list price consumers expect in retailers with low price image could have a stronger impact on price fairness, and further increase the customer satisfaction. Contrary, it is empirically shown that if retailers with higher price image will take strategic pricing choice inconsistent with their higher image, price unfairness can be reduced by a large margin, and then result in lower consumer dissatisfaction.

\section{Theoretical Implications}

Theoretically, we showed that price image which a retailer is communicating to consumers have an impact on consumer behavior through price fairness and customer satisfaction. That is, using the framework of perception - emotion behavior perspective based on expectancy value theory, we empirically identified the effect of retailer's price image on price fairness, consumer satisfaction and loyalty, focusing on the relationship between the retailer's price image and price fairness consumer perceived. This kind of explanation could be theoretical basis for strategic pricing selection of retailers, which existing studies related to store image couldn't explain. The result is the same as the finding of Mittal and Kamakura (2001) indicating that consumer satisfaction have a positive effect on repurchase intention, and the arguments of Anderson, Fornell and Mazvancheryl (2004) and Kumar et al. (2013) studies demonstrating that while high customer satisfaction can leads to positive word-of-mouth, high consumer dissatisfaction can produce a negative complaining behavior. Moreover, the result of this study also is in line with the conceptual research like Hamilton and Chernev (2013) and Xia et al. (2004)

\section{CONCLUSIONS}

The retailer's price image on price fairness is related to consumer behavior leading to satisfaction and loyalty. The representative consequence of consumer satisfaction can be repurchasing intention, which has positive impact on consumer satisfaction. The consumers perceive a retailer with low price image as fairer than other retailers. Nevertheless, more fair the consumers perceive, the more they are satisfied and higher will be the repurchase intention and publicity through word of mouth. Hence, there is need for at least moderate relationship between the dealer's price image and the price fairness. 


\section{REFERENCES}

1. Anderson, Eugene W., ClaesFornell, and Sanal K. Mazvancheryl (2004), "Customer satisfaction and shareholder value," Journal of Marketing, 68 (4), 172-85.

2. Bolton, Lisa E., LukWarlop, and Joseph W. Alba (2003), "Consumer perceptions of price (un) fairness, "Journal of Consumer Research, 29 (4), 474-91.

3. Boush, David M., and Barbara Loken (1991), "A process-tracing study of brand extension evaluation," Journal of Marketing Research, 28 (1), 16-28.

4. Buttle, Francis, and Jamie Burton (2002), "Does service failure influence customer loyalty?" Journal of Consumer Behaviour, $1(3), 217-27$.

5. Campbell, Margaret C. (1999), "Perceptions of price unfairness: Antecedents and consequences," Journal of Marketing Research, 36 (2), 187-99.

6. Chebat, Jean-Charles, and WitoldSlusarczyk (2005), "How emotions mediate the effects of perceived justice on loyalty in service recovery situations: An empirical study," Journal of Business Research, 58 (5), 664-73.

7. Estelami, Hooman, and Peter De Maeyer (2004), "Product category determinants of price knowledge for durable consumer goods," Journal of Retailing, 80 (2), 129-37.

8. Hamilton, Ryan, and Alexander Chernev (2013), "Low prices are just the beginning: Price image in retail management," Journal of Marketing, 77 (6), 1-20.

9. Herrmann, Andreas, Lan Xia, Kent B. Monroe, and Frank Huber (2007), "The influence of price fairness on customer satisfaction: An empirical test in the context of automobile purchases, "Journal of Product \& Brand Management, 16 (1), 49 58.

10. Keller, Kevin L., and David A. Aaker (1992), "The effects of sequential introduction of brand extensions," Journal of Marketing Research, 29 (1), 35-50.

11. Kumar, V., IlariaDallaPozza, and Jaishankar Ganesh (2013), "Revisiting the satisfaction-loyalty relationship: Empirical generalizations and directions for future research," Journal of Retailing, 89 (3), 246-62.

12. Mittal, Vikas, and Wagner A. Kamakura (2001), "Satisfaction, repurchase intent, and repurchase behavior: Investigating the moderating effect of customer characteristics, " Journal of Marketing Research, 38 (1), 131-42

13. Morgan, Robert M., and Shelby D. Hunt (1994), "The commitment-trust theory of relationship marketing," Journal of Marketing, 58 (3), 20-38.

14. Oliver, Richard L., and John E. Swan (1989), "Equity and disconfirmation perceptions as influences on merchant and product satisfaction," Journal of Consumer Research, 16 (3), 372-83.

15. Seiders, Kathleen, Glenn B. Voss, DhruvGrewal, and Andrea L. Godfrey (2005), "Do satisfied customers buy more? Examining moderating influences in a retailing context," Journal of Marketing, 69 (4), 26-43.

16. Sirdeshmukh, Deepak, Jagdip Singh, and Barry Sabol (2002), "Consumer trust, value, and loyalty in relational exchanges," Journal of Marketing, 66 (1), 15-37.

17. Vanhuele, Marc, and Xavier Drèze (2002), "Measuring the price knowledge shoppers bring to the store," Journal of Marketing, 66 (4), $72-85$.

18. Xia, Lan, Kent B. Monroe, and Jennifer L. Cox (2004), "The price is unfair! A conceptual framework of price fairness 
perceptions, " Journal of Marketing, 68 (4), 1-15.

19. Zeithaml, Valarie A. (1988), "Consumer perceptions of price, quality, and value: A means-end model and synthesis of evidence, "Journal of Marketing, 52 (3), 2-22.

20. Zielke, Stephan (2006), "Measurement of retailers' price images with a multiple-item scale," The International Review of Retail, Distribution and Consumer Research, 16 (3), 297-316. 